\title{
Acetylcholine Receptor-like Molecules Are Found in Both Synaptic and Extrasynaptic Clusters on the Surface of Neurons in the Frog Cardiac Ganglion
}

\author{
Peter B. Sargent and Danny Z. Pang \\ Division of Biomedical Sciences, University of California, Riverside, California 92521
}

\begin{abstract}
Sixty monoclonal antibodies (mAbs) made against nicotinic acetylcholine receptors (AChRs) from electric organ were tested for their ability to cross-react at synaptic sites in the frog cardiac ganglion, where transmission is mediated by $A C h$ via nicotinic receptors. Forty-one of the mAbs tested were known to bind to AChRs in frog skeletal muscle (Sargent et al., 1984). As determined by double-label immunofluorescence microscopy, 8 of the 60 mAbs bound to small, punctate sites that lay within areas of synaptic contact, marked by an anti-synaptic vesicle antibody. One of the 8 cross-reacting antibodies that produced particularly intense staining (mAb 22) was chosen for further study and was found to bind to the postsynaptic membrane beneath active zones, as determined by peroxidase immunocytochemistry and electron microscopy. This suggests that mAb 22 crossreacts with AChRs on the ganglion cell surface. While most mAb 22 immunoreactivity was located in the postsynaptic membrane, about $20 \%$ of the peroxidase-stained patches were extrasynaptic (327 patches analyzed from 8 ganglia). Virtually no peroxidase-stained patches were observed when an isotype-matched control mAb was used in place of $\mathrm{mAb}$ 22. In frog skeletal muscle peroxidase-stained patches obtained with mAb 22 were found exclusively at synaptic sites (179 patches examined from 6 muscles). These results suggest that extrasynaptic patches of AChRs are present in innervated autonomic neurons but not in innervated skeletal muscle.
\end{abstract}

Although nicotinic acetylcholine receptors (AChRs) have been extensively characterized in skeletal muscle, relatively little is known about them in neuronal systems. This discrepancy is due to the absence of a rich natural source of neuronal AChRs and to the fact that, until recently, specific ligands for neuronal receptors have not been available. During the past several years, 3 useful classes of probes for neuronal receptors have emerged. The first of these is neuronal bungarotoxin ( $n$-bgt; formerly known as bungarotoxin 3.1 , toxin $F$, and $\kappa$-bungarotoxin), a toxin from

Received June 24, 1988; revised Aug. 17, 1988; accepted Aug. 18, 1988.

This work was supported by NIH Grants NS 22491 and NS 24207. We wish to thank Jon Lindstrom for his continued support and advice and for providing the 60 rat monoclonal anti-receptor antibodies used in this study. We also thank Lou Reichardt and John Bixby for the gift of mouse monoclonal antibody asv48, John Kitasako for technical assistance with the electron microscopy, and Zach Hall, Jon Lindstrom, and Dale Purves for reviewing a preliminary version of the manuscript.

Correspondence should be addressed to Dr. Peter B. Sargent at the above address.

Copyright (c) 1989 Society for Neuroscience $0270-6474 / 89 / 031062-11 \$ 02.00 / 0$ krait venom that blocks neuronal AChR function (reviewed by Chiappinelli, 1985, and Lindstrom et al., 1987). The second class of probes is a subset of antibodies made against electric organ AChR which cross-reacts with neuronal receptors (Marshall, 1981; Swanson et al., 1983, 1987; Jacob et al., 1984; Whiting and Lindstrom, 1986, 1987; Whiting et al., 1987; Sargent et al., 1989). The third set of probes are cDNA probes which recognize portions of $A C h R$-like sequences found in brain cDNA libraries and which bind to AChR-rich areas of brain upon in situ hybridization (Boulter et al., 1985, 1986; Barnard et al., 1986; Goldman et al., 1986, 1987). The recent and intensive use of these ligands has greatly increased our understanding of neuronal nicotinic AChR structure and distribution. For example, Marshall (1981), working on frog sympathetic neurons, and Jacob et al. (1984), working on chick ciliary neurons, found, using cross-reacting antibodies combined with peroxidase immunocytochemistry and electron microscopy, that neuronal AChR-like immunoreactivity is concentrated in punctate patches lying immediately beneath active zones. Quantitative electron microscopic autoradiography using ${ }^{125}$ I-n-bgt hinding to chick ciliary ganglion cells suggests that the density of AChRs in the postsynaptic membrane is on the order of 600 toxin binding sites $/ \mu \mathrm{m}^{2}$ of membrane (Loring and Zigmond, 1987), or perhaps 20 -fold less than it is in skeletal muscle, where the density is more than 10,000 sites $/ \mu \mathrm{m}^{2}$ (Porter and Barnard, 1975; Fertuck and Salpeter, 1976; Matthews-Bellinger and Salpeter, 1978). We have utilized cross-reacting monoclonal antibodies specific for neuronal AChRs and peroxidase immunocytochemistry to uncover another apparent difference between skeletal muscle and nerve. In the frog cardiac ganglion approximately $20 \%$ of the patches of AChR-like immunoreactivity are located at extrasynaptic sites (see also Jacob et al., 1984). In frog skeletal muscle analyzed using identical techniques, no extrasynaptic patches of immunoreactivity are present. These results suggest that a sizable fraction of $\mathrm{AChR}$ clusters on the neuronal surface, but not the myofiber surface, are extrasynaptic.

A preliminary account of these results has been published (Sargent and Lindstrom, 1987).

\section{Materials and Methods}

Animals and dissections. Rana pipiens were obtained from IIazen Co. (Alburg, VT) and housed at room temperature in chambers where they had access to both water and a dry platform. Xenopus laevis were obtained from the laboratory breeding colony. Frogs were cooled to near $0^{\circ} \mathrm{C}$ in an ice/water bath, decapitated, and pithed, and the interatrial septum and cutaneous pectoris muscles (Rana only) were removed and dissected in frog Ringer's (114 mM NaCl, $2.0 \mathrm{~mm} \mathrm{KCl}, 2.0 \mathrm{mM} \mathrm{CaCl}_{2}$, 5.0 mM HEPES, pH 7.4). 
Enzyme treatment. In order to promote access of macromolecules, such as immunoglobulins, to the surface of the cardiac ganglion cells, interatrial septa were incubated at $37^{\circ} \mathrm{C}$ for $1 \mathrm{hr}$ in $1 \mathrm{mg} / \mathrm{ml}$ collagenase (type II, Sigma) and for $0.5 \mathrm{hr}$ in $0.1 \mathrm{mg} / \mathrm{ml}$ protease (subtilisin, Bochringer-Mannheim). This sequential procedure is similar to that described by Betz and Sakmann (1971) and by Baluk and Fujiwara (1984). Enzyme treatment dissociates much of the tissue in the septum, leaving only the nerve trunks intact.

Immunofluorescence. Two-color immunofluorescence experiments to visualize both $\mathrm{AChRs}$ and synaptic sites in protease-treated tissue were done by fixing cardiac ganglia in $0.75 \%$ paraformaldehyde (PFA) in 0.10 $\mathrm{M} \mathrm{Na}$ phosphate for $1 \mathrm{hr}$ and then by incubating tissue with the following solutions (all incubations were done at room temperature; in some experiments membranes were permeabilized by preincubation in $0.025 \%$ saponin in Ringer's for 20 min): (1) Ringer's containing $10 \%$ normal goat serum (hereafter, $R G$ ) for $10 \mathrm{~min}$, (2) $20 \mathrm{~nm}$ rat $\mathrm{mAb}$ in $\mathrm{RG}$ for 1 hr (titer determined using electric organ AChR; see Tzartos et al., 1981, for details), (3) RG for 30 min (3 changes), (4) 50-300 nM fluoresceinconjugated goat anti-rat IgG (Fl-GARt) in RG for $1 \mathrm{hr}$, (5) RG for 20 min (2 changes), (6) Ringer's for $10 \mathrm{~min}$, (7) $1 \% \mathrm{PFA}$ in $0.1 \mathrm{M} \mathrm{Na}$ phosphate for 1 hr, (8) Ringer's for 20 min, (9) Ringer's containing $0.025 \%$ saponin for $20 \mathrm{~min}$ (to permeabilize the tissue), (10) Ringer's for $10 \mathrm{~min}$, (11) RG for $10 \mathrm{~min}$, (12) mouse mAb asv48 (from Dr. Lou Keichardt) in $\mathrm{RG}$ for $\mathrm{l} \mathrm{hr}$, (13) $\mathrm{KG}$ for 30 min (3 changes), (14) rhodamine-conjugated goat anti-mouse IgG (Rh-GAM) for $1 \mathrm{hr}$ [Rh-GAM was cleansed of its cross-reactivity with rat $\mathrm{IgG}$ by prior incubation with rat IgG-agarose (Sigma) and centrifugation], (15) RG for $20 \mathrm{~min}$ (2 changes), (16) Ringer's for $10 \mathrm{~min},(17) 1 \% \mathrm{PFA}$ in $0.1 \mathrm{M} \mathrm{Na}$ phosphate for $1 \mathrm{hr}$, (18) Ringer's for $10 \mathrm{~min}$, (19) $70 \%$ glycerol $/ 30 \%$ Ringer's for $10 \mathrm{~min}$, and (20) $90 \%$ glycerol $/ 10 \%$ Ringer's for $10 \mathrm{~min}$. Tissue was then mounted between 2 coverslips in Citifluor (a buffered, glycerolbased mountant that retards bleaching) and viewed and photographed using a Nikon Microphot-FX microscope with $100 \mathrm{~W}$ mercury lamp and $60 \times$ planapo objective.

Peroxidase immunocytochemistry. Electron microscopic visualization of AChRs by immunoperoxidase techniques in protease-treated ganglia was done with the $a$ vidin biotinylated HRP complex (ABC) technique of Hsu and Raine (1981). Peroxidase-treated tissue was fixed in PFA (as above) and then incubated in the following solutions: (1) RG for 10 min, (2) $20 \mathrm{nM}$ rat $\mathrm{mAb}$ in $\mathrm{RG}$ for $1 \mathrm{hr}$, (3) RG for 30 min (3 changes), (4) biotinylated rabbit anti-rat IgG (RbARt, diluted 1:200 in $R G$, from Vector Laboratories' Vectastain kit; goat serum proved to be a more effective blocking reagent in these experiments, even though the second antibody was made in rabbit), (5) RG for 30 min (3 changes), (6) HRPavidin (diluted 1:100 from the Vectastain kit) for $1 \mathrm{hr},(7) \mathrm{RG}$ for 20 min (2 changes), (8) Ringer's for $10 \mathrm{~min}$, (9) $1 \%$ glutaraldehyde in 0.06 $\mathrm{M}$ Na phosphate buffer, $\mathrm{pH} 7.2$, for $1 \mathrm{hr}$, and (10) Ringer's for $10 \mathrm{~min}$. Reaction product was generated with diaminobenzidine using the glucose oxidase technique as described by Itoh et al. (1979). Tissue was then incubated in $1 \% \mathrm{OsO}_{4}$ in $0.09 \mathrm{M}$ Na phosphate, $\mathrm{pH} 7.2$, dehydrated in ethanol, and embedded in Epon/araldite. Block staining, when appropriate, was done in aqueous $2 \%$ uranyl acetate for $30 \mathrm{~min}$. Sections having a silver interference color were made using a Reichert Ultramicrotome and viewed in a Hitachi $\mathrm{H}-600$ electron microscope without grid staining.

Immunoperoxidase visualization of $\mathrm{mAb}$ binding was also done in the absence of protease treatment, but not via the $\mathrm{ABC}$ technique, since the large HRP-avidin complex does not penetrate into the synaptic cleft even after $24 \mathrm{hr}$ of incubation. Rather, a 2 -step procedure was used in which tissue was treated with primary mAb for $20-24 \mathrm{hr}$ and subsequently with HRP-GARt-F(ab') (Cappel) for 20-24 hr. Wash steps following these incubations were increased to $1-2 \mathrm{hr}$.

Experiments were done with both control and experimental antibodies in parallel, so that incubation and reaction conditions would be identical. For each condition, we attempted to analyze 100 nucleuscontaining cell profiles in the electron microscope, with each profile representing a unique neuron. The perimeter of each profile was scanned in the electron microscope at $8000 \times(80,000 \times$, including magnification of oculars), and each peroxidase-stained patch on the cell surface was photographed at $40,000 \times$. The linear length of the patches is then measured on EM negatives using a digitizing pad and a microcomputer.

Colloidal gold immunoelectron microscopy. Colloidal gold (3 nm) was made by the citrate-tannic acid method of Slot and Geuze (1985), conjugated to protein A by the method of Slot and Geuze (1981), and purified using a modification of a procedure described by Wray and
Sealock (1984). Rat $\mathrm{mAb}$ binding was visualized as described in steps 1-10 above for the immunoperoxidase technique except that rabbit antirat $\mathrm{IgG}$ (diluted to $20 \mathrm{~nm}$, Cappel) was used in step 4 and gold-protein A (diluted to an O.D. of 1.0 at $525 \mathrm{~nm}$ ) in step 6 . Tissue was then osmicated, dehydrated, and embedded without running the histochemical reaction.

\section{Results}

The frog cardiac ganglion is a collection of more than 1000 parasympathetic neurons embedded within the thin interatrial septum (McMahan and Kuffler, 1971). The neurons, or ganglion cells, are situated primarily along 2 nerve trunks, which are continuations of the paired cardiac branches of the vagosympathetic nerves (so-called because they contain both sympathetic and parasympathetic components). Each unipolar ganglion cell body is innervated by a single preganglionic axon (Sargent, 1986), which terminates in a number of en passant and terminal synaptic boutons. The boutons, which are the sites from which the transmitter ACh is released, occupy about 3\% of the cell body surface (McMahan and Kuffler, 1971). Regions of the cell surface having boutons are known to be more sensitive to iontophoretically applied ACh than randomly chosen sites (Harris et al., 1971; Roper, 1976), presumably because the postsynaptic membrane is enriched in AChRs (Marshall, 1981; Jacob et al., 1984; Loring and Zigmond, 1987).

If cardiac ganglia are incubated for an hour in high concentrations of HRP, little or no tracer is found to have penetrated into the synaptic cleft (data not shown). This diffusion barrier is not overcome by saponin, which does permit access to both the pre- and the postsynaptic cell (Sargent et al., 1984). Therefore, the barrier is not cellular but acellular and is probably the result of extracellular matrix. One way to overcome this diffusion barrier is to disrupt the matrix with protease. The technique used was similar to that first described by Hall and Kelly (1971) and Betz and Sakmann $(1971,1973)$ as modified by Baluk and Fujiwara (1984). Unfixed cardiac ganglia were treated with collagenase $\left(37^{\circ} \mathrm{C}, 1 \mathrm{hr}\right)$ and then with subtilisin $\left(37^{\circ} \mathrm{C}, 30 \mathrm{~min}\right)$. Under these conditions there is relatively little disjunction of synaptic boutons, and the satellite cell processes remain on the ganglion cell surface. Protease treatment does not appear to adversely affect neuromuscular transmission when synapses remain physically intact (Betz and Sakmann, 1973), signifying that the AChR is sufficiently intact to permit its ion channel to be gated by ACh.

\section{Antibody binding characterized by light microscopy}

MAbs made against electric organ AChR were tested for their ability to bind to synaptic sites in the cardiac ganglion using a 2 -color fluorescence assay. Tissue was protease-treated, lightly fixed, treated with rat $\mathrm{mAb}$ and then with Fl-GARt. In order to locate synaptic sites in the same tissue, we followed the FlGARt step with a mouse $\mathrm{mAb}$ (asv48) that recognizes a synaptic vesicle antigen (Matthew et al., 1981) and, finally, with $\mathrm{Rh}$ GAM. When used with some mAbs, this technique produced small, brightly fluorescent spots on the surface of the cell. A typical result produced by a positive rat $\mathrm{mAb}$ is illustrated in Figure 1, which shows, at the same focal plane, Nomarski $(A)$, rhodamine $(B)$, and fluorescein $(C)$ micrographs of a pair of ganglion cell bodies. Small, brightly fluorescent spots $(C)$ are secn that correspond in position to synaptic boutons $(B)$. There are usually several fluorescein spots associated with a single bouton. No spots were seen when normal rat serum was used in place of a positive $\mathrm{mAb}$ (data not shown). 

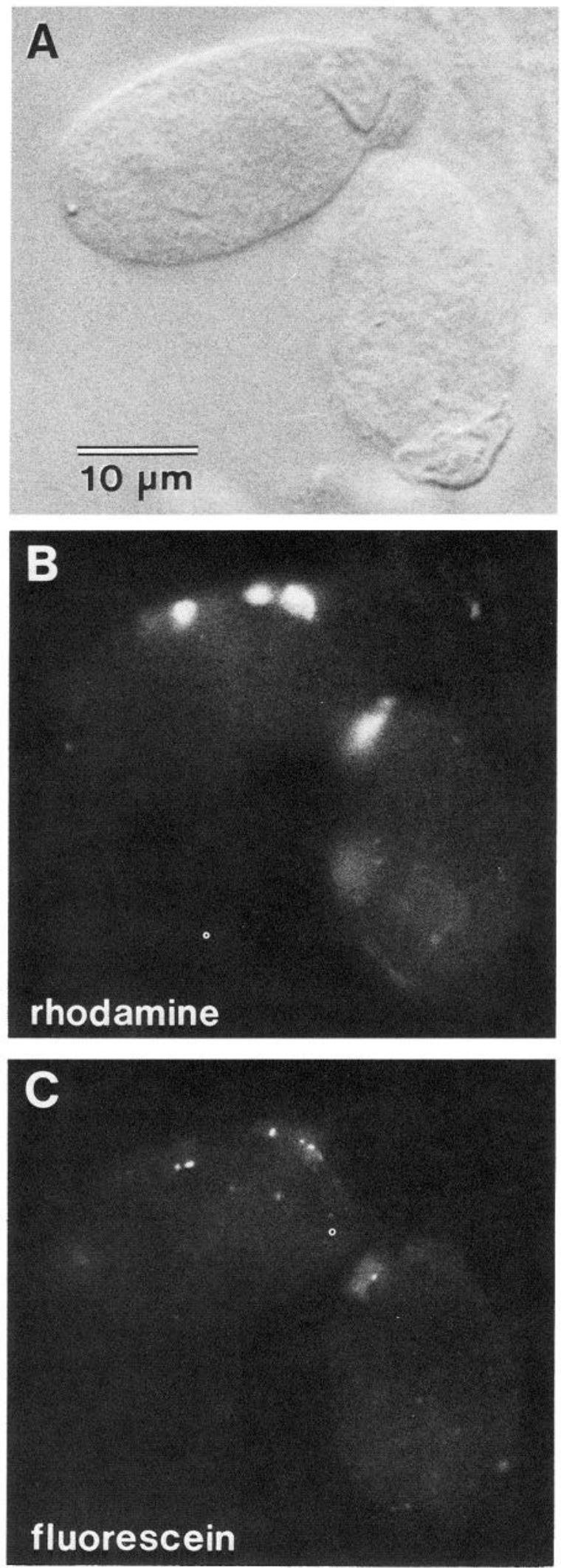

Figure 1. Light microscopic fluorescence assay for $\mathrm{mAb}$ binding to synaptic sites in the cardiac ganglion. A cardiac ganglion was incubated in succession with $\mathrm{mAb} 22$, with fluorescein-labeled goat anti-rat IgG, mouse antibody asv 48 (which recognizes an antigen on synaptic vesicles), and finally rhodamine-labeled goat anti-rat IgG. The 3 micrographs in the figure were taken of the same field using Nomarski $(A)$,
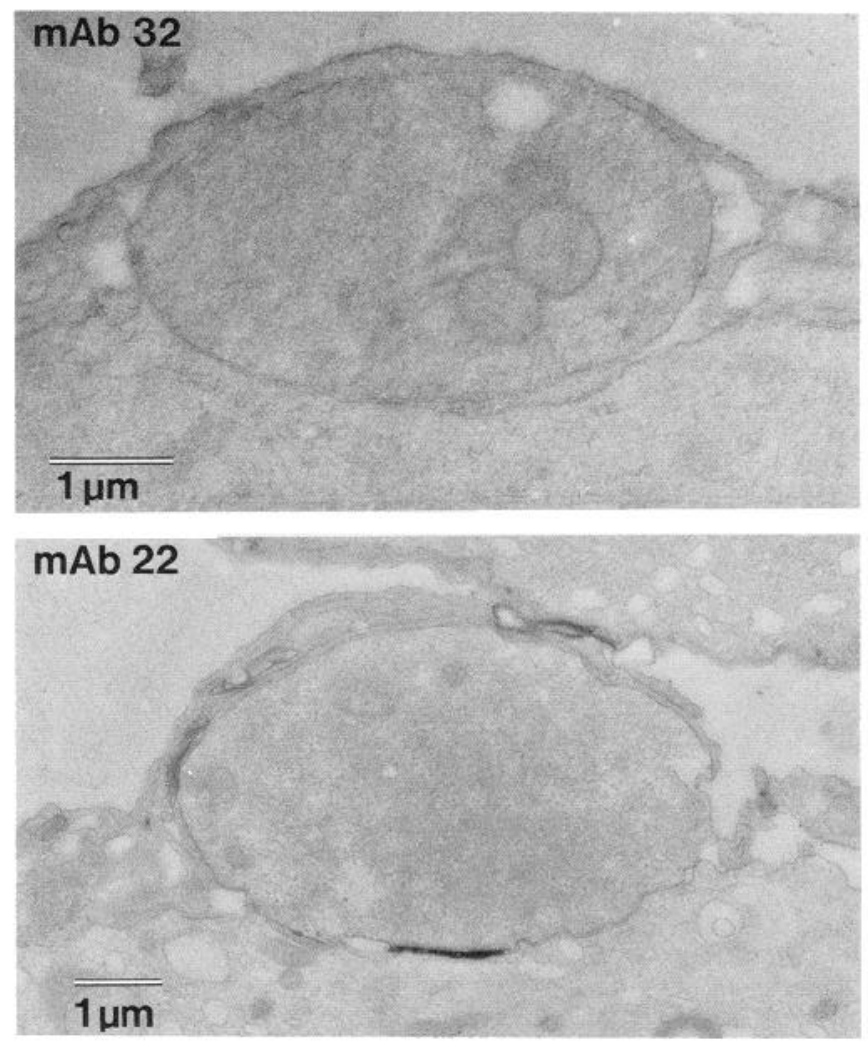

Figure 2. Electron microscopic demonstration of anti-AChR binding to synaptic sites in the cardiac ganglion. Two electron micrographs of synaptic boutons are shown, one taken from an experiment using control mAb 32 (top) and one using mAb 22 (bottom). Antibody binding was visualized using the $A B C$ technique (Hsu and Raine, 1981). The images are of low contrast because the tissue was not block-stained and because tannic acid was omitted from the glutaraldehyde during fixation. The lack of contrast enhances the visibility of the peroxidase reaction product (compare with Fig. 3). Specific staining (with mAb 22 only) is found in a patch that occupies only a fraction of the bouton contact area.

Eight of 60 rat mAbs tested bound selectively to synaptic sites in the double-label fluorescence assay (Table 1). All 8 of the cross-reacting $\mathrm{mAbs}$ are specific for the main immunogenic region (MIR) of electric organ AChR: a highly immunogenic and highly conserved set of overlapping epitopes on the $\alpha$ subunit of the electric organ AChR (Tzartos et al., 1981). None of the $8 \mathrm{mAbs}$ bound to synaptic sites in the cardiac ganglion of $X$. laevis, presumably because $X$. laevis AChRs do not have an MIR (Sargent et al., 1984). Table 1 lists subunit specificity when tested against electric organ AChR as well as whether the mAb binds to AChRs in frog skeletal muscle (Sargent et al., 1984) and to AChR-like molecules in frog optic tectum (Sargent et al., 1989). Each AChR (skeletal muscle, optic tectum, cardiac ganglion) is antigenically distinct (Table 1).

\section{Antibody binding characterized by electron microscopy}

Antibody binding to synaptic sites in the electron microscope was visualized using the $\mathrm{ABC}$ immunoperoxidase technique (Hsu

rhodamine (B), and fluorescein $(C)$ optics. The sites of mAb 22 binding $(C)$ correspond in position to the location of synaptic boutons $(B)$. Usually there are multiple spots of immunoreactivity associated with each bouton. 

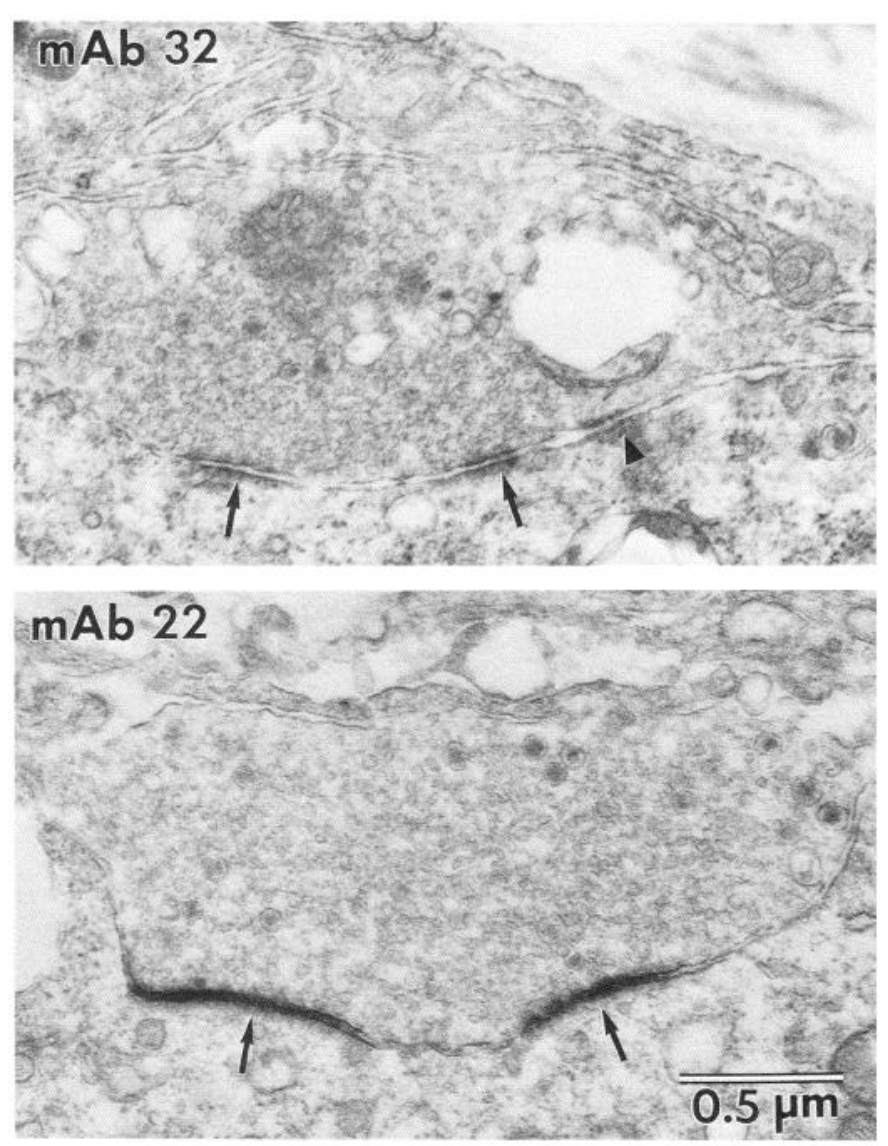

Figure 3. Electron microscopic demonstration of anti-AChR antibody binding to synaptic sites in the cardiac ganglion, with active zones revealed by inclusion of tannic acid in the glutaraldehyde step and by block staining with uranyl acetate. Two electron micrographs are shown, one taken from an experiment using control mAb 32 (top) and one taken from an experiment using $\mathrm{mAb} 22$. Antibody binding was visualized using the ABC technique (Hsu and Raine, 1981). Arrows indicate the location of active zones, the probable sites of transmitter release. $\mathrm{Ar}$ rowhead in top micrograph indicates a probable punctum adhaerens. Reaction product with $\mathrm{mAb} 22$ is intense and fills the synaptic cleft. No specific reaction product is observed with $\mathrm{mAb} 32$.

and Raine, 1981). Figure 2 shows a pair of synaptic boutons taken from tissue incubated with control $\mathrm{mAb} 32$ (top) and with mAb 22 (bottom). MAb 32 is an anti-electric organ mAb that is completely species specific; it is an ideal control for nonspecific binding since it is the same isotype (IgG2b) as mAb 22. The tissue in Figure 2 was neither block- nor grid-stained in order to clearly reveal the presence of peroxidase stain. The specific staining (bottom) is restricted to a part of the contact area. The staining entirely fills the synaptic cleft, as it often does when AChRs are visualized at synaptic sites in skeletal muscle using peroxidase immunocytochemistry (e.g., Sargent et al., 1984). The presence of stain within the cleft and on the presynaptic membrane is presumably the result of diffusion of peroxidase reaction product (Courtoy et al., 1983).

In order to learn whether the stain seen in Figure $2 B$ is restricted to that part of the contact area containing active zones, we examined peroxidase immunoreactivity in block-stained tissue. Figure 3 shows representative examples of sections through active zones from block-stained tissue treated with mAb 32 (top) and with mAb 22 (bottom). In a ganglion incubated with control $\mathrm{mAb} 32$, we found no peroxidase staining at any of 39 active
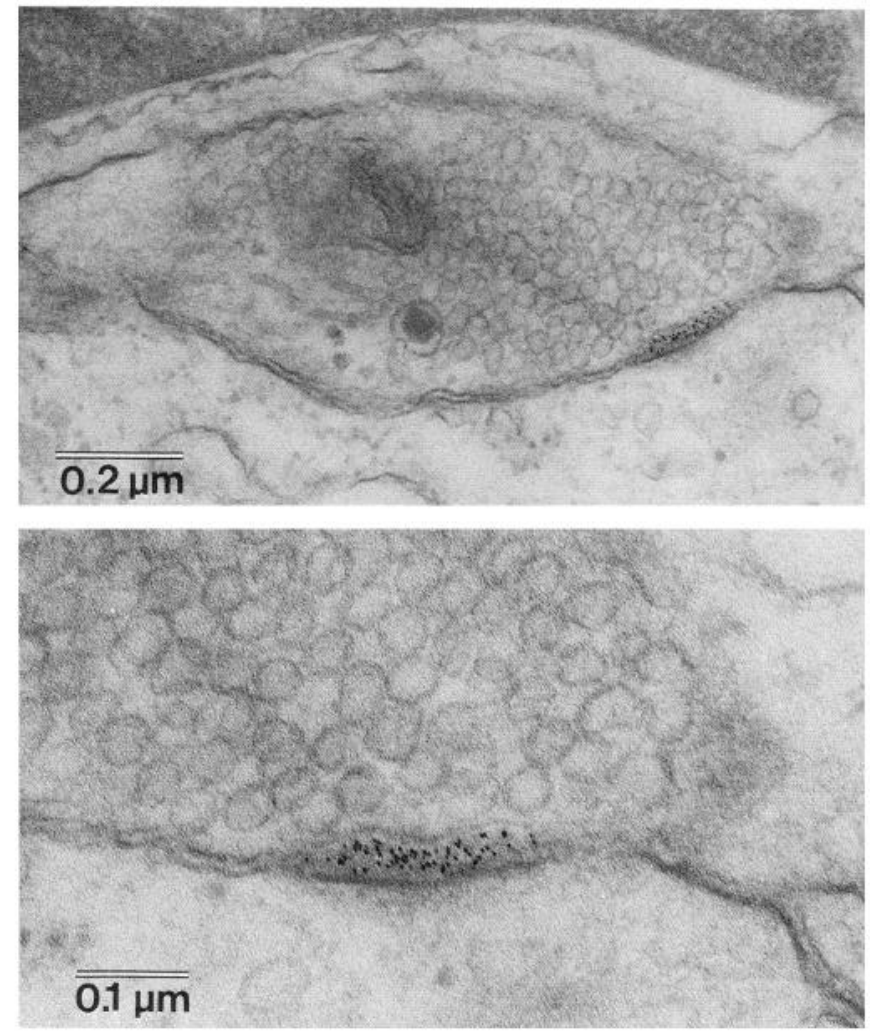

Figure 4. Electron microscopic visualization of AChR-like immunoreactivity using immunogold techniques. Top, Synaptic bouton with a dense cluster of gold particles within the synaptic cleft (shown at higher magnification below). AChR-like immunoreactivity was visualized using $\mathrm{mAb} 22$, rabbit anti-rat IgG and protein A-colloidal gold $(3 \mathrm{~nm}$ particle size). The gold particles are located at an active zone, recognized by the postsynaptic density. Active zones are often more readily identified in immunogold experiments than in immunoperoxidase ones since reaction product does not obliterate the synaptic cleft. The protein Agold reagent penetrates into only parts of the tissue in protease-treated ganglia and labels AChRs in only a small fraction of active zones.

zones from 29 boutons (active zones were defined by the presence of both pre- and postsynaptic electron-dense specializations and by a cluster of presynaptic vesicles; only profiles with sharply defined pre- and postsynaptic membranes were scored). In a second ganglion, run in parallel with the first but with $\mathrm{mAb}$ 22 , we found immunoreactivity at 44 of 45 sites marked by active zones ( 37 boutons scored; see Figure 3, bottom), and we found no patches of immunoreactivity away from active zones. Thus, virtually all of the immunoreactivity at areas of bouton contact is restricted to areas of the ganglion cell surface opposite active zones.

We have also been able to view anti-AChR antibody binding using $3 \mathrm{~nm}$ colloidal gold conjugated to protein A. Figure 4 (top) shows a micrograph of a bouton with a dense cluster of gold particles within the synaptic cleft. The particles are present at an active zone on the basis of its postsynaptic electron-dense specialization (Fig. 4, bottom). Since the gold particles are found throughout the cleft, it is not possible to conclude that mAb 22 binds selectively to the postsynaptic membrane. One reason for the poor resolution of this gold technique is that the procedure uses protein $\mathrm{A}$, a rod-shaped molecule with a probable length that is comparable to the width of the synaptic cleft (Bjork et al., 1972). The protease treatment used to promote access of 


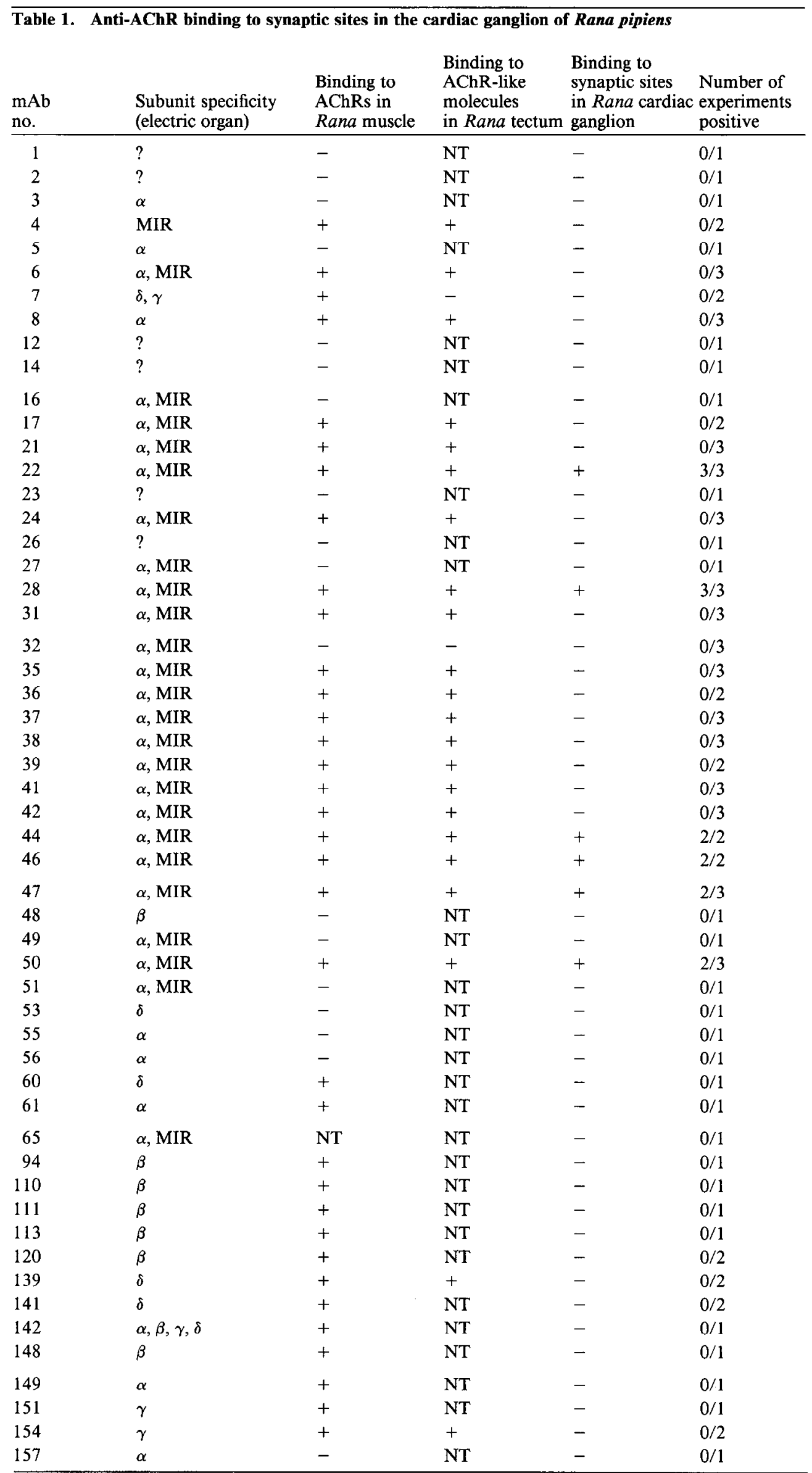




\begin{tabular}{|c|c|c|c|c|c|}
\hline $\begin{array}{l}\text { mAb } \\
\text { no. }\end{array}$ & $\begin{array}{l}\text { Subunit specificity } \\
\text { (electric organ) }\end{array}$ & $\begin{array}{l}\text { Binding to } \\
\text { AChRs in } \\
\text { Rana muscle }\end{array}$ & $\begin{array}{l}\text { Binding to } \\
\text { AChR-like } \\
\text { molecules } \\
\text { in Rana tectum }\end{array}$ & $\begin{array}{l}\text { Binding to } \\
\text { synaptic sites } \\
\text { in Rana cardiac } \\
\text { ganglion }\end{array}$ & $\begin{array}{l}\text { Number of } \\
\text { experiments } \\
\text { positive }\end{array}$ \\
\hline 165 & $\gamma$ & + & NT & - & $0 / 2$ \\
\hline 166 & $\delta$ & + & NT & - & $0 / 1$ \\
\hline 168 & $\gamma, \beta$ & + & NT & - & $0 / 1$ \\
\hline 176 & MIR & + & NT & - & $0 / 1$ \\
\hline 177 & MIR & + & + & + & $3 / 3$ \\
\hline 188 & MIR & + & + & + & $3 / 3$ \\
\hline
\end{tabular}

All mAbs were made against electric organ AChR or AChR subunits and were characterized as described in Tzartos and Lindstrom (1980) and Tzartos et al. $(1981,1986)$. Reactivity with AChRs in skeletal muscle was determined by Sargent et al. (1984), and with AChRs as described by Sargent et al. (1989). Only 8 of the 60 mAbs cross-reacted with synaptic sites in the ganglion (Fig. 1). All 8 cross-reacting mAbs are specific for the main immunogenic region (MIR). NT, not tested.

macromolecules to the synaptic cleft occasionally causes synaptic disjunction (Betz and Sakmann, 1973), so that some boutons are lifted away from the ganglion cell surface. Under such conditions we find that the immunoreactivity is usually restricted to the postsynaptic membrane, as illustrated in Figure 5 for an immunoperoxidase experiment. The appearance of weak peroxidase immunoreactivity on the nerve terminal of disjoined synapses (Fig. 5) may reflect the presence of presynaptic AChRs but may alternatively reflect the fact that peroxidase reaction product is capable of diffusing some distance before precipitating (Courtoy et al., 1983). The issue of presynaptic receptors would best be addressed at disjoined synapses using EM autoradiography (Jones and Salpeter, 1983) or colloidal gold techniques to visualize AChRs.

Our results show that mAb 22 binds preferentially to the postsynaptic membrane in the frog cardiac ganglion. This result, taken together with the fact that mAb 22 specifically binds to AChRs in eel electric organ (Tzartos et al., 1981), strongly suggests that it is binding to AChRs in the cardiac ganglion. Our argument is strengthened by the recent findings of Berg and his colleagues with $\mathrm{mAb} 35$ which, like $\mathrm{mAb} 22$, is an anti-MIR antibody made in rats against eel AChR (Jacob et al., 1984; Halvorsen and Berg, 1987). These investigators showed that $\mathrm{mAb} 35$ bound to synaptic sites in the chick ciliary ganglion and that mAb 35 binds to the AChR itself, since it immunoprecipitates the AChR-specific binding of n-bgt in tissue extracts.

\section{Quantitative analysis of $A C h R$ patches on the ganglion cell surface}

Clusters of AChRs on the neuronal cell surface were examined quantitatively using immunoperoxidase cytochemistry and electron microscopy. The peroxidase technique has high spatial resolution compared with autoradiography and is ideal for examining the location and size of clusters of AChR present in high density. But the technique is not as sensitive as autoradiography; for example, it does not typically reveal extrasynaptic AChRs in denervated skeletal muscle, which are present at relatively low density (Lentz et al., 1977; Burden et al., 1979).

The general approach in analyzing the ganglion cell surface for high-density clusters of AChRs was to scan large numbers of cell profiles for the presence of patches of peroxidase stain. A total of 615 profiles, each from a unique cell, was examined from ganglia treated with either control (mAb 32) or experi- mental (mAb 22) mAb. The average number of peroxidasestained patches observed with mAb 22 was 0.81 patches per cell profile $[ \pm 0.06$ (SD), $n=4$ experiments, with an average of 100 cell profiles examined for each experiment]; in contrast, the average number of patches observed with mAb 32 was 0.01 patches per cell profile $(n=2$ experiments, both mAbs were used at a titer of $20 \mathrm{~nm}$ ). Thus, the extent of nonspecific staining is on the order of $1 \%$ of total staining and can be ignored. The incidence of 0.81 patches per cell profile for normally innervated ganglia corresponds to about $0.4 \%$ of the cell surface and is equivalent to several dozen patches of high-density AChRs per whole cell body.

An analysis of AChR patches on normally innervated ganglion cells revealed an unexpected result. Figure 6 shows prominent patches of peroxidase stain, indicative of high AChR density, beneath 2 synaptic boutons. Both patches of stain appear

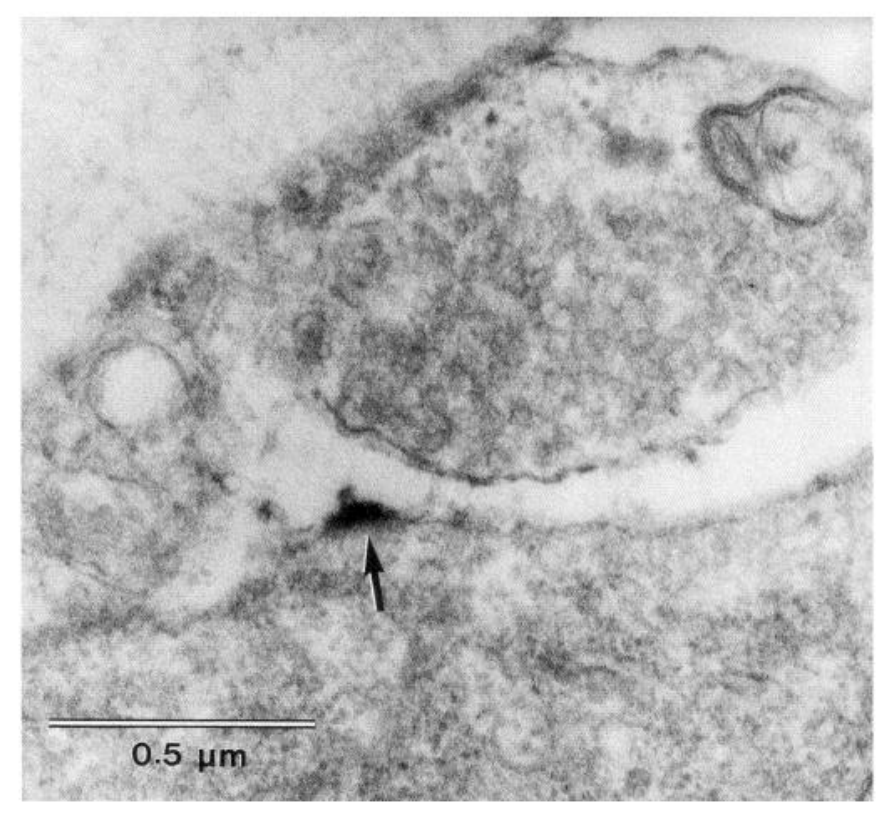

Figure 5. Immunoperoxidase visualization of AChR-like immunoreactivity on the postsynaptic membrane at a disjoined terminal. At a synaptic bouton disjoined by collagenase and subtilisin the peroxidase reaction product (arrow), visualized using $\mathrm{mAb} 22$ and the $\mathrm{ABC}$ technique, is restricted largely to the postsynaptic surface. 


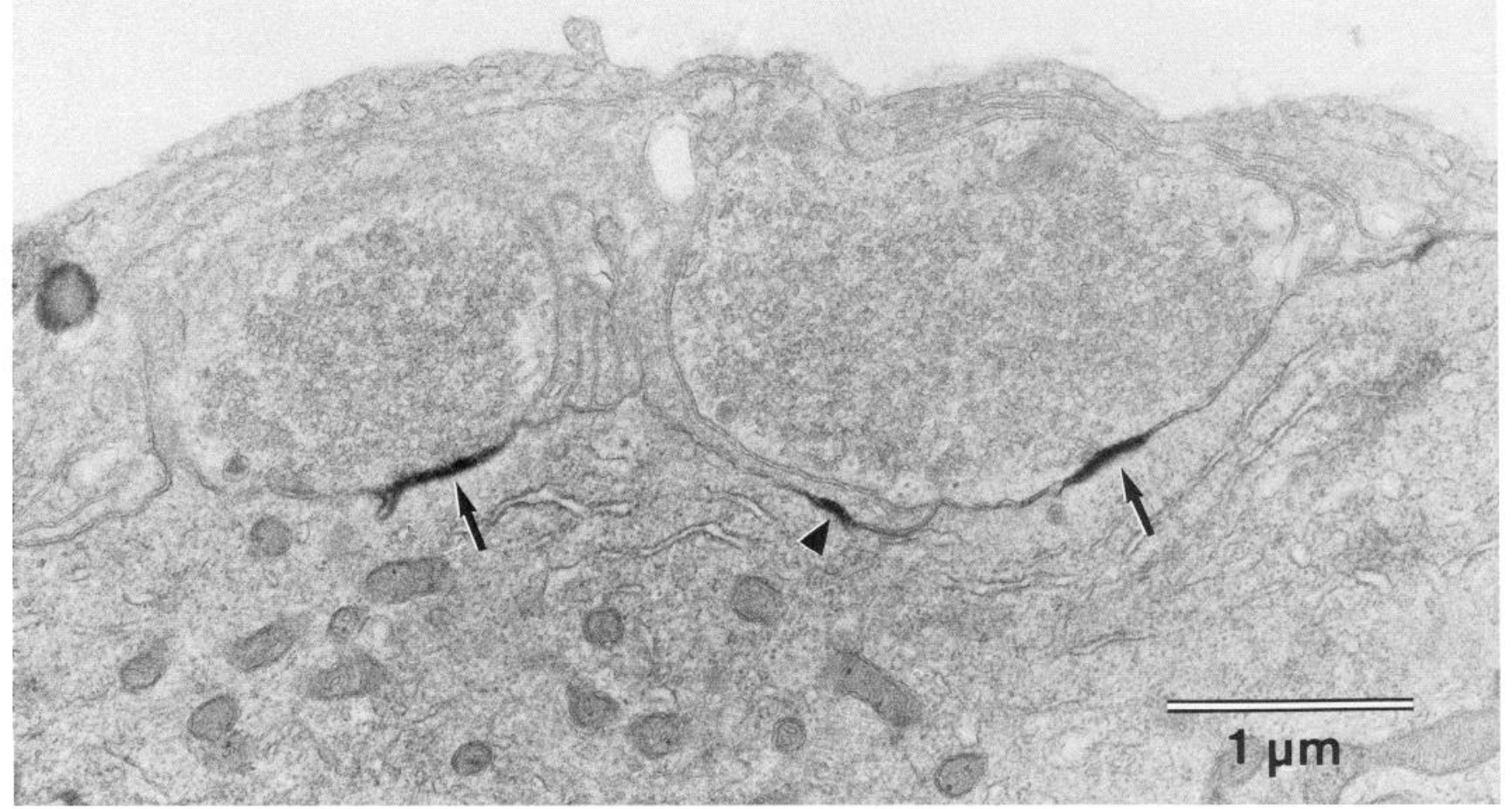

Figure 6. AChR-like immunoreactivity is located on both the synaptic and the extrasynaptic ganglion cell surface. Immunoreactivity was visualized using $\mathrm{mAb} 22$ and the $\mathrm{ABC}$ technique. Patches of dense peroxidase stain are associated with 2 boutons (arrows) but also with at least one site on the ganglion cell surface not contacted by a bouton (arrowhead). The image is of low contrast (as in Fig. 2) in order to enhance the appearance of the peroxidase reaction product.

to be situated at active zones, but there is at least one other patch of stain in Figure 6 that does not lie at a site of bouton contact. This presumably represents an extrasynaptic patch of AChR. Such extrasynaptic patches of immunoreactivity were also observed using colloidal gold techniques (data not shown). Many immunoperoxidase-stained patches were located in the vicinity of boutons (as in Fig. 6), but a systematic search using light microscopy or serial section electron microscopy was not made to learn whether all extrasynaptic patches were perisynaptic. Of a total of 327 patches of peroxidase stain, $78 \pm 2 \%$ were located beneath boutons and $22 \pm 2 \%$ were not (mean \pm SD, $n=4$ experiments). Jacob et al. (1984) also reported the existence of extrasynaptic AChR patches in the chick ciliary ganglion.

Extrasynaptic AChR patches are slightly smaller than synaptic ones. The average linear length of synaptic patches in thin sections was $0.34 \pm 0.05 \mu \mathrm{m}$, while the average linear length of extrasynaptic patches is $0.25 \pm 0.02 \mu$ m (mean $\pm \mathrm{SD}, n=4$ experiments, $p<0.02$ by student's $t$ test). The surface area of extrasynaptic patches is therefore likely to be about half that of synaptic patches [calculated by squaring the ratio of linear dimensions; $\left.(0.25 / 0.34)^{2}\right]$.

The distribution of AChR-like immunoreactive patches on the ganglion cell surface is highly asymmetric, with about $80 \%$ of the patches within the $3 \%$ of the cell surface contacted by boutons (McMahan and Kuffler, 1971). If the macromolecular reagents used to label AChRs in these experiments do not have access to the entire surface of the cell, then the observed patch distribution might not necessarily reflect the actual distribution of $\mathrm{AChR}$ clusters. However, when ganglia are incubated with collagenase and subtilisin for 2-3 times the usual length, large sections of the cell surface are exposed to the bulk extracellular space (see also Baluk and Fujiwara, 1984). Under these conditions, a distribution qualitatively similar to that observed after milder conditions prevails. Peroxidase-stained patches of immunoreactivity are located primarily beneath boutons (Fig. 7). This suggests that the general pattern of patch distribution is not likely to result from selective access of reagents to synaptic portions of the ganglion cell surface under conditions of mild proteolysis.

We have recently discovered an alternative to protease treatment for staining the postsynaptic membrane with $\mathrm{mAb} 22$ and HRP-labeled secondary reagents. Although antibodies do not penetrate the synaptic cleft in $1 \mathrm{hr}$ without protease, they will do so if incubation times are increased to $24 \mathrm{hr}$. Figure 8 shows the result of incubating intact, fixed septa with primary antibody followed by HRP-labeled goat anti-rat $\mathrm{F}\left(\mathrm{ab}^{\prime}\right)_{2}$ [HRP-GARt$\mathrm{F}\left(\mathrm{ab}^{\prime}\right)_{2}$ ]. [Experiments using the larger HRP-avidin complex $(M W$ $>500 \mathrm{k}$ ?) did not work, suggesting that compounds considerably larger than IgGs do not penetrate into the synaptic cleft in 24 hr.] Active-zone-specific peroxidase staining was again observed with mAb 22 but not with control mAb 32. When AChR-like immunoreactivity was visualized without protease treatment, we still found extrasynaptic patches of stain: In one experiment 8 of 53 immunoreactive patches (15\%) were extrasynaptic, and in a second experiment, 11 of 68 immunoreactive patches $(16 \%)$ 


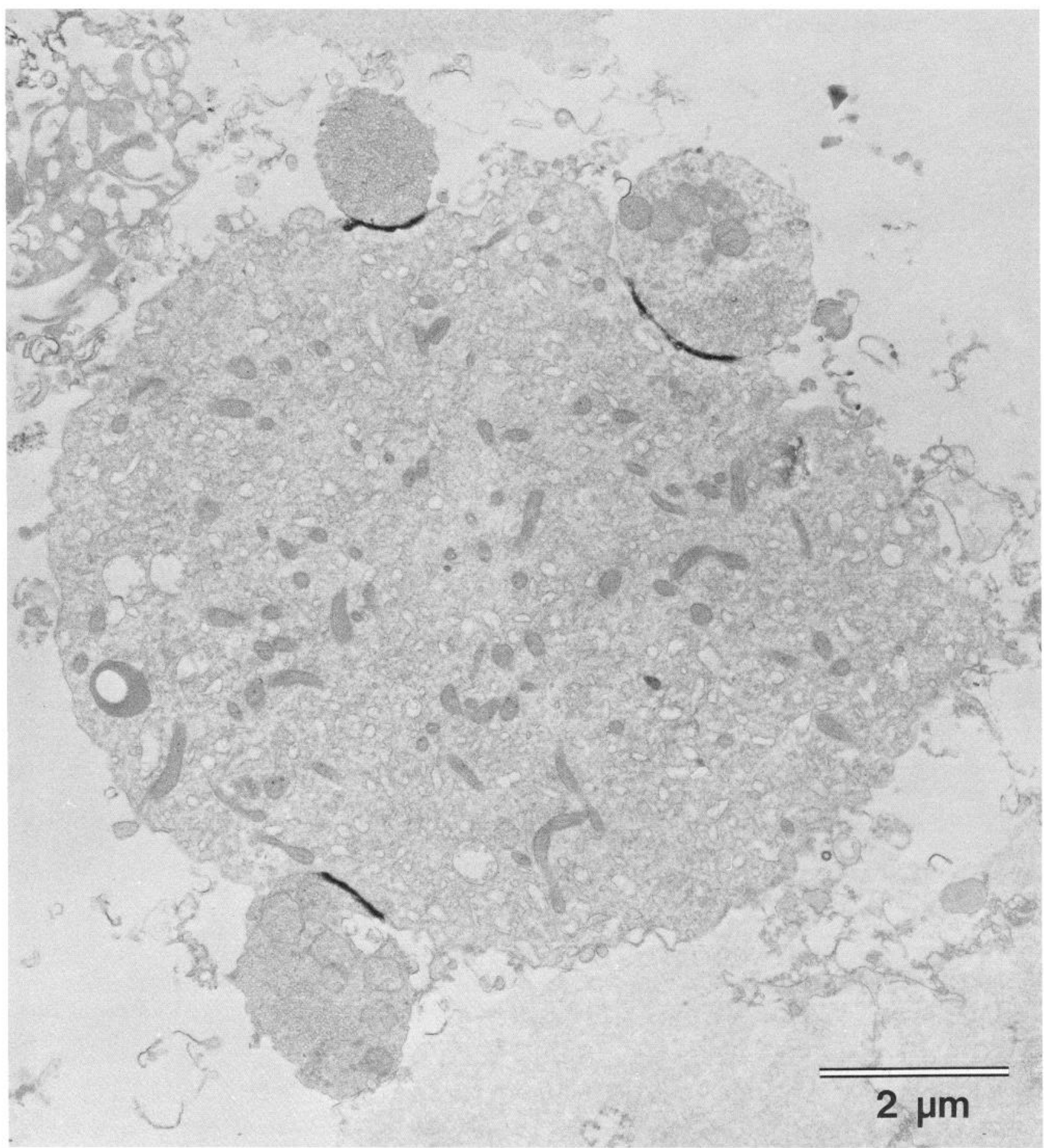

Figure 7. Electron micrograph of AChR-like immunoreactivity on a ganglion cell stripped of its satellite cell coverings prior to the immunoperoxidase procedure. A cardiac ganglion was treated with collagenase and subtilisin for 2-3 times the usual length, fixed, and then incubated with mAb 22 and with secondary and tertiary reagents to visualize AChR-like immunoreactivity (Hsu and Raine, 1981). The prolonged protease incubation often leaves substantial portions of the cell surface exposed. Under these conditions, immunoreactivity is found preferentially at synaptic sites. Here, reaction product is located exclusively at 3 sites of bouton contact. The length of the peroxidase stain generally was no greater after prolonged protease treatment than it was normally.

were extrasynaptic. Extrasynaptic patches were slightly less common than when experiments included protease pretreatment $(22 \pm 2 \%$, mean $\pm \mathrm{SD})$. This suggests that protease treatment may artificially convert a small number of synaptic patches to extrasynaptic ones, possibly by disjunction. However, the frequency with which extrasynaptic patches of AChR-like im- munoreactivity are found in the absence of protease treatment indicates clearly that they are not an artifact of protease usage. In skeletal muscle, high-density clusters of $\mathrm{AChRs}$ are reported to be located exclusively at synaptic sites (e.g., Dreyer and Peper, 1974; Lentz et al., 1977). In order to make neuronmyofiber comparisons more meaningful, we visualized AChRs 

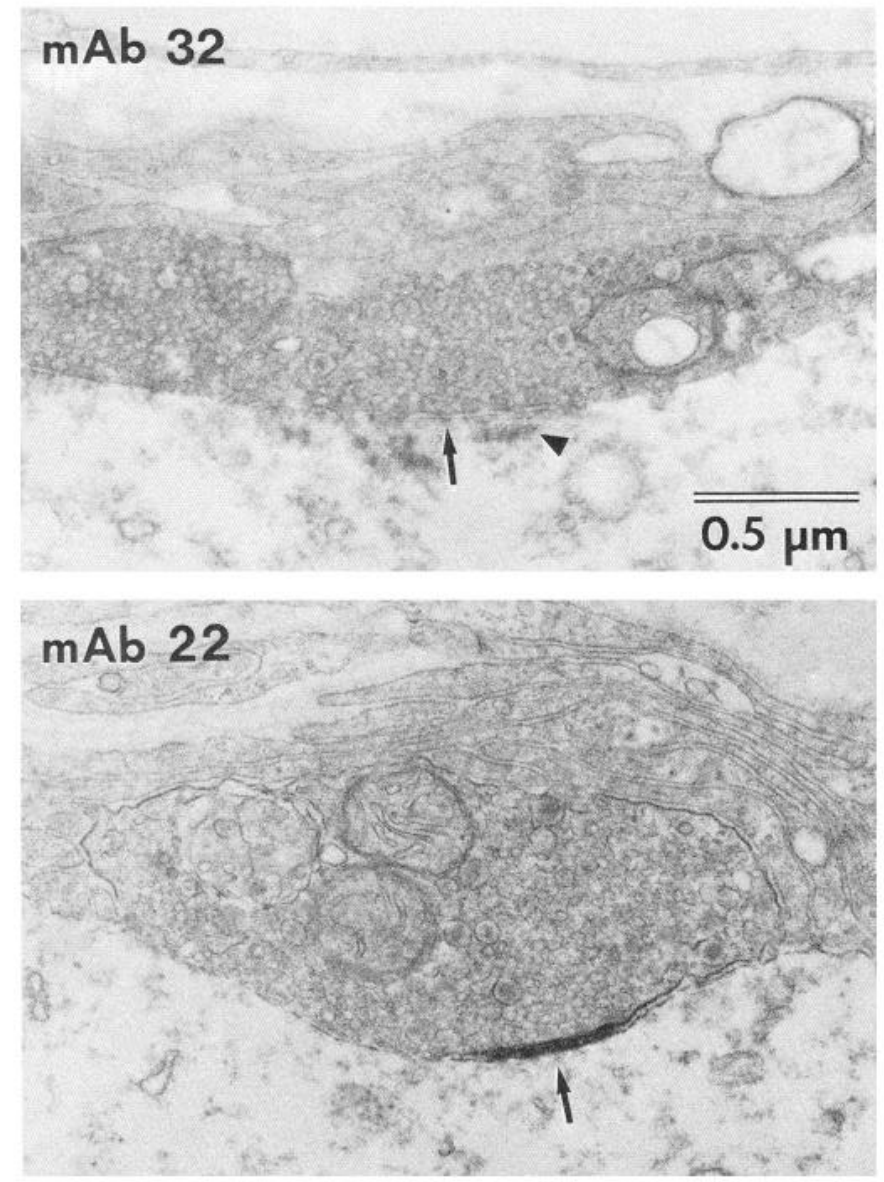

Figure 8. Electron microscopic demonstration of AChR-like immunoreactivity at synaptic sites in cardiac ganglia not treated with protease. Access of antibodies was made possible by lengthening incubation times from $1 \mathrm{hr}$ to $1 \mathrm{~d}$. Two electron micrographs of synaptic boutons are shown, one from an experiment using control $\mathrm{mAb} 32$ and one using $\mathrm{mAb} 22$. MAb binding was visualized using HRP-conjugated $\mathrm{F}\left(\mathrm{ab}^{\prime}\right)_{2}$ fragments of goat anti-rat IgG. Active zones are indicated by arrows. The arrowhead in the top micrograph points out a subsynaptic bar (Taxi, 1976).

in normally innervated skeletal muscle using mAb 22 and immunoperoxidase procedures identical to those used in the cardiac ganglion (mAb 22 binds to Rana skeletal muscle AChRs: Sargent et al., 1984). In a total of 744 fiber cross sections from 6 cutaneous pectoris muscles examined in 2 experiments, we found 179 patches of peroxidase immunoreactivity, all of which were located at synapses (identified by the presence of the nerve terminal). Skeletal muscle thus appears to lack extrasynaptic high-density AChR patches.

\section{Discussion}

\section{AChR-like immunoreactivity and AChRs}

The distribution of binding of $\mathrm{mAb} 22$ in the cardiac ganglion is similar to that expected for a ligand that recognizes AChRs. Immunoreactivity is found predominantly in small patches on the postsynaptic membrane which correspond in position to that of active zones, marked by electron-dense specializations in the presynaptic membrane. Immunoreactivity is found at virtually all active zones, several of which may be associated with a single bouton, but not found elsewhere at sites of bouton contact. A very similar pattern of immunoreactivity was found by Marshall (1981) and by Jacob et al. (1984) at other interneuronal nicotinic synapses. Marshall (1981) showed in bullfrog sympathetic ganglia that both polyclonal anti-AChR sera and HRP- $\alpha$-bungarotoxin bound selectively to the postsynaptic membrane. Unlike the situation at many interneuronal nicotinic synapses, $\alpha$-bungarotoxin binds to AChRs in bullfrog sympathetic ganglia and blocks receptor function. Jacob et al. (1984, 1986) found in the chick parasympathetic ciliary ganglion that anti-AChR mAb 35 binds selectively to the postsynaptic membrane. The likelihood that this binding reflects the presence of AChRs is very high, since mAb 35 has been shown to immunoprecipitate AChR-specific binding of neuronal bungarotoxin (n-bgt), indicating that it and n-bgt bind to a common molecule (Halvorsen and Berg, 1987).

MAb 22 recognizes AChRs in several species, including electric organ of eel and Torpedo (Tzartos et al., 1981), skeletal muscle of Rana and Xenopus (Sargent et al., 1984) and goldfish brain (Henley et al., 1986). This fact, together with the fact that the distribution of mAb 22 binding on the neuronal surface is similar to that produced by other AChR-specific ligands used by others and that an antibody with a similar specificity (mAb 35 ) binds to AChRs in another neuronal system strongly suggest that $\mathrm{mAb} 22$ is binding to AChRs in the cardiac ganglion.

\section{Antigenic structure of the neuronal AChR}

Only 8 of the 60 anti-AChR mAbs tested appear to cross-react with neuronal AChRs in the cardiac ganglion. Since 41 of these mAbs cross-react with AChRs in skeletal muscle, there are several epitopes which frog skeletal myofibers, but not frog parasympathetic neurons, appear to share with electric organ AChR. All 8 of the cross-reacting mAbs are specific for the MIR, which is located on the extracellular surface of the electric organ's $\alpha$ subunit (Tzartos and Lindstrom, 1980; Sargent et al., 1984) and which includes, at least in part, amino acids 67-76 in human muscle AChR (Barkas et al., 1988; Tzartos et al., 1988) and 6876 in Torpedo electric organ AChR (M. Das and J. Lindstrom, unpublished observations). The MIR in electric organ and skeletal muscle is highly conserved across species since a large number of MIR-specific mAbs react with AChRs from a number of species, including calf, rat, and frog (Tzartos and Lindstrom, 1980; Tzartos et al., 1981; Sargent et al., 1984). Although there are homologies within the MIR between nerve and muscle, there are also differences, since 14 of the 22 anti-MIR mAbs that cross-react with muscle AChRs do not cross-react with ganglion AChRs. None of $18 \mathrm{mAbs}$ that recognize intracellular epitopes and cross-react with AChRs in frog skeletal muscle (Sargent et al., 1984) bind at synaptic sites in the cardiac ganglion, even when incubations are performed on tissue permeabilized with saponin. The differences in cross-reactivity observed with mAbs recognizing intracellular epitopes probably also reflect genuine differences between neuronal and muscle AChRs (reviewed by Lindstrom et al., 1987).

There is a clear antigenic distinction between AChRs in the cardiac ganglion and $\mathrm{AChR}$-like molecules in the optic tectum (Table 1). The MIR of the tectal AChR-like molecule is very similar to that of muscle AChR, with the same set of 22 antiMIR mAbs cross-reacting with each, and it is quite different from that of the AChR in cardiac ganglion, where only 8 of these $22 \mathrm{mAbs}$ are positive. This is in keeping with results from other laboratories indicating that neuronal AChRs comprise a family of AChRs rather than a single type (reviewed by Lindstrom et al., 1987). 


\section{Extrasynaptic AChR patches}

The existence of a sizable number of extrasynaptic patches of AChR-like immunoreactivity in normally innervated neurons is unexpected. Jacob et al. (1984) reported finding AChR-like immunoreactivity in the form of peroxidase-stained patches on the nonsynaptic surface of chick ciliary ganglion cells, although this staining represented "a small fraction of the total (ligand) binding." In the cardiac ganglion we find that about $20 \%$ of the patches of AChR-like immunoreactivity are located at extrasynaptic sites. We have not made a systematic evaluation of the distribution of extrasynaptic patches; many, however, are located in the vicinity of boutons (as in Fig. 6). The existence of extrasynaptic patches of immunoreactivity cannot be attributed to synaptic disjunction or rearrangement caused by protease treatment since they are observed when the protease treatment is omitted and when antibody incubations are done on fixed tissue. These patches likewise cannot be attributed to nonspecific binding of $\mathrm{mAb}$ since this represents about $1 \%$ of the total binding whereas extrasynaptic patches represent about $20 \%$ of the total binding. We estimate that an average ganglion cell body might contain perhaps $30-40$ patches of immunoreactivity associated with 12 synaptic boutons (McMahan and Kuffler, 1971) and about 7-10 extrasynaptic patches. If AChRs in extrasynaptic patches are functional, then they could underlie some of the extrasynaptic sensitivity to iontophoretically applied $\mathrm{ACh}$ observed in several autonomic ganglia (Harris et al., 1971; Roper, 1976; Dennis and Sargent, 1979; Dunn and Marshall, 1985); some of this sensitivity, though, is undoubtedly the result of diffusion of $\mathrm{ACh}$ to nearby synaptic sites.

Why do the parasympathetic ganglion cells in the frog heart have extrasynaptic patches of AChR immunoreactivity? In skeletal muscle the motor nerve terminal induces the initial formation of AChR clusters and maintains them even as individual receptor molecules are degraded and replaced (reviewed by Schuetze and Role, 1987). Since AChR-like clusters are enriched at sites of nerve contact in the cardiac ganglion and elsewhere (Harris et al., 1971; Roper, 1976; Marshall, 1981; Jacob et al., 1984; Loring and Zigmond, 1987), one is led to conclude that here, as in muscle, the preganglionic axon induces and maintains AChR clusters. In skeletal muscle there are no AChR clusters located away from the site of nerve contact, and it is natural to wonder why there are in the cardiac ganglion. One appealing possibility is that these clusters represent the recent past (or future) distribution of synaptic boutons on the surface of the cell. Experiments in which the distribution of boutons on the surface of autonomic neurons is monitored in vivo suggest that their physical location on the cell surface can change over the course of weeks, either because they move or because their replacements are not constrained to occupy the same site (Purves et al., 1987). If a bouton were to move, its postsynaptic specialization might linger for some time, permitting its detection. The current information about nerve terminals in skeletal muscle suggests that they are more stable physically than terminals on autonomic neurons (Herrera and Banner, 1987; Lichtman et al., 1987; Wigston, 1987), and thus one might not expect to find vacated $A C h R$ patches in muscle with any regularity.

The finding that normally innervated parasympathetic neurons in frog have significant numbers of extrasynaptic $A C h R-$ like clusters, which presumably reflect true AChRs, points to the existence of a fundamental difference in $\mathrm{AChR}$ distribution in muscle and nerve. This difference, and others involving AChR density (Loring and Zigmond, 1987) and AChR regulation by the presynaptic axon (Jacob and Berg, 1987), suggests that the neuromuscular junction may not generally be a good model for interneuronal synapses.

\section{References}

Baluk, P., and T. Fujiwara (1984) Direct visualization by scanning electron microscopy of the preganglionic innervation and synapses of the true surfaces of neurons in the frog heart. Neurosci. Lett. 51:265270.

Barkas, T., J.-M. Gabriel, A. Mauron, G. J. Hughes, B. Roth, C. Alliod, S. J. Tzartos, and M. Ballivet (1988) Monoclonal antibodies to the main immunogenic region of the nicotinic acetylcholine receptor bind to residues $61-76$ of the $\alpha$-subunit. J. Biol. Chem. 263: 5916-5920.

Barnard, E., V. Beeson, M. Cockcroft, M. Darlison, A. Hicks, F. A. Lai, S. Moss, and M. D. Squire (1986) Molecular biology of nicotinic acetylcholine receptors from chicken muscle and brain. In Nicotinic Acetylcholine Receptor, NATO ASI Series, Vol. H3, A. Maelicke, ed., pp. 389-415, Springer-Verlag, Heidelberg.

Betz, W., and B. Sakmann (1971) "Disjunction" of frog neuromuscular synapses by treatment with proteolytic enzymes. Nature [New Biol.] 232: 94-95.

Betz, W., and B. Sakmann (1973) Effects of proteolytic enzymes on function and structure of frog neuromuscular junctions. J. Physiol. (Lond.) 230: 673-688.

Bjork, I., B.-A. Petersson, and J. Sjoquist (1972) Some physicochemical properties of protein A from Staphylococcus aureus. Eur. J. Biochem. 29: 579-584.

Boulter, J., W. Luyten, K. Evans, P. Mason, M. Ballivet, D. Goldman, S. Stengelin, G. Martin, S. Heinemann, and J. Patrick (1985) Isolation of a clone coding for the $\alpha$-subunit of a mouse acetylcholine receptor. J. Neurosci. 5: 2545-2552.

Boulter, J., K. Evans, D. Goldman, D. Martin, D. Treco, S. Heinemann, and J. Patrick (1986) Isolation of a cDNA clone coding for a possible neural nicotinic acetylcholine receptor $\alpha$-subunit. Nature 319: 368374 .

Burden, S. J., P. B. Sargent, and U. J. McMahan (1979) Acetylcholine receptors in regenerating muscle accumulate at original synaptic sites in the absence of the nerve. J. Cell Biol. 82: 412-425.

Chiappinelli, V.A. (1985) Actions of snake venom toxins on neuronal nicotinic receptors and other neuronal receptors. Pharmacol. Ther. 31: $1-32$.

Courtoy, P. J., D. H. Dicton, and M. G. Farquhar (1983) Resolution and limitation of the immunoperoxidase procedure in the localization of extracellular matrix antigens. J. Histochem. Cytochem. 31: 945951.

Dennis, M. J., and P. B. Sargent (1979) Loss of extrasynaptic acetylcholine sensitivity upon reinnervation of parasympathetic ganglion cells. J. Physiol. (Lond.) 289: 263-275.

Dreyer, F., and K. Peper (1974) The acetylcholine sensitivity in the vicinity of the neuromuscular junction. Pfluegers Arch. 348: 273286.

Dunn, P. M., and L. M. Marshall (1985) Lack of nicotinic supersensitivity in frog sympathetic neurones following denervation. J. Physiol. (Lond.) 363: 211-225.

Fertuck, H. C., and M. M. Salpeter (1976) Quantitation of junctional and extrajunctional acetylcholine receptors by electron microscope autoradiography after ${ }^{125} \mathrm{I}$ - $\alpha$-bungarotoxin binding at mouse neuromuscular junction. J. Cell Biol. 69: 144-158.

Goldman, D., D. Simmons, L. W. Swanson, J. Patrick, and S. Heinemann (1986) Mapping of brain areas expressing RNA homologous to two acetylcholine receptor $\alpha$-subunit cDNAs. Proc. Natl. Acad. Sci. USA 83: 4076-4080.

Goldman, D., E. Deneris, W. Luyten, A. Kochlar, J. Patrick, and S. Heinemann (1987) Members of a nicotonic acetylcholine receptor gene family are expressed in different regions of the mammalian central nervous system. Cell 48: 965-973.

Hall, Z. W., and R. B. Kelly (1971) Enzymatic detachment of endplate acetylcholinesterase from muscle Nature [New Biol.] 232: 62-63.

Halvorsen, S. W., and D. K. Berg (1987) Affinity labeling of neuronal acetylcholine receptor subunits with an alpha-neurotoxin that blocks receptor function. J. Neurosci. 7: 2547-2555.

Harris, A. J., S. W. Kuffler, and M. J. Dennis (1971) Differential chemosensitivity of synaptic and extrasynaptic areas on the neuronal 
surface membrane in parasympathetic neurons of the frog, tested by microapplication of acetylcholine. Proc. R. Soc. London [Biol.] 177: 541-553.

Henley, J. M., M. Mynlicff, J. M. Lindstrom, and R. E. Oswald (1986) Interaction of monoclonal antibodies to electroplaque acetylcholine receptors with the $\alpha$-bungarotoxin binding site of goldfish brain. Brain Res. 364: 405-408.

Herrera, A. A., and L. R. Banner (1987) Direct observation of motor nerve terminal remodelling in living frogs. Soc. Neurosci. Abstr. 13: 1665 .

Hsu, S.-M., and L. Raine (1981) Protein A, avidin and biotin in immunohistochemistry. J. Histochem. Cytochem. 229: 1349-1353.

Itoh, K., A. Konishi, S. Nomura, N. Mizuno, Y. Nakamura, and T. Sugimoto (1979) Application of coupled oxidation reaction to electron microscopic demonstration of horseradish peroxidase: Cobaltglucose oxidase method. Brain Res. 175: 341-346.

Jacob, M. H., and D. K. Berg (1987) Effects of preganglionic denervation and postganglionic axotomy on acetylcholine receptors in the chick ciliary ganglion. J. Cell Biol, 105: 1847-1854.

Jacob, M. H., D. K. Berg, and J. M. Lindstrom (1984) Shared antigenic determinants between Electrophorus acetylcholine receptor and a synaptic component on chicken ciliary ganglion neurons. Proc. Natl. Acad. Sci. USA 81: 3223-3227.

Jacob, M. H., J. M. Lindstrom, and D. K. Berg (1986) Surface and intracellular distribution of a putative neuronal nicotinic acetylcholine receptor. J. Cell Biol. 103: 205-214.

Jones, S. W., and M. M. Salpeter (1983) Absence of [ $\left.{ }^{125} \mathrm{I}\right] \alpha$-bungarotoxin binding to motor nerve terminals of frog, lizard and mouse muscle. J. Neurosci. 3: 326-331.

Lentz, T. L., J. E. Mazurkiewicz, and J. Rosenthal (1977) The cytochemical localization of acetylcholine receptors at the neuromuscular junction by means of horseradish peroxidase-labeled $\alpha$-bungarotoxin. Brain Res. 132: 423-442.

Lichtman, J. W., L. Magrassi, and D. Purves (1987) Visualization of neuromuscular junctions over periods of several months in living mice. J. Neurosci. 7: 1215-1222.

Lindstrom, J., R. Schoepfer, and P. Whiting (1987) Molecular studies of the neuronal nicotinic acetylcholine receptor family. Mol. Neurobiol. 1: 281-337.

Loring, R. H., and R. E. Zigmond (1987) Ultrastructural distribution of ${ }^{125}$ I-toxin $F$ binding sites on chick ciliary neurons: Synaptic localization of a toxin that blocks ganglionic nicotinic receptors. J. Neurosci. 7: 2153-2162.

Marshall, L. M. (1981) Synaptic localization of $\alpha$-bungarotoxin binding which blocks nicotinic transmission at frog sympathetic neurons. Proc. Natl. Acad. Sci. USA 78: 1948-1952.

Matthew, W. D., L. Tsavaler, and L. F. Reichardt (1981) Identification of a synaptic vesicle-specific membrane protein with a wide distribution in neuronal and neurosecretory tissue. J. Cell Biol. 91: 257269.

Matthews-Bellinger, J., and M. M. Salpeter (1978) Distribution of acetylcholine receptors at frog neuromuscular junctions with a discussion of some physiological implications. J. Physiol. (Lond.) 279: 197-213.

McMahan, U. J., and S. W. Kuffler (1971) Visual identification of synaptic boutons on living ganglion cells and of varicosities in postganglionic axons in the heart of the frog. Proc. R. Soc. London [Biol.] 177: 485-508.

Porter, C. W., and E. A. Barnard (1975) Distribution and density of cholinergic receptors at the motor end-plates of a denervated mouse muscle. Exp. Neurol. 48: 542-556.

Purves, D., J. T. Voyvodic, L. Magrassi, and H. Yawo (1987) Nerve terminal remodeling visualized in living mice by repeated examination of the same neuron. Science 238: 1122-1126.

Roper, S. (1976) The acetylcholine sensitivity of the surface membrane of multiply-innervated parasympathetic ganglion cells in the mudpuppy before and after partial denervation. J. Physiol. (Lond.) 254: $455-473$.

Sargent, P. B. (1986) Relationship between synaptic size and target cell size in the parasympathetic cardiac ganglion of Xenopus laevis. Soc. Neurosci. Abstr. 12: 1502.

Sargent, P. B., and J. M. Lindstrom (1987) The binding of anti-acetylcholine receptor antibodies to synaptic sites at interneuronal synapses in the frog cardiac ganglion. Soc. Neurosci. Abstr. 13: 796.

Sargent, P. B., B. E. Hedges, L. Tsavaler, L. Clemmons, S. Tzartos, and J. M. Lindstrom (1984) The structure and transmembrane nature of the nicotinic acetylcholine receptor in amphibian muscle as revealed by cross-reacting monoclonal antibodies. J. Cell Biol. 98: 609618.

Sargent, P. B., S. H. Pike, D. B. Nadel, and J. M. Lindstrom (1989) Nicotinic acetylcholine receptor-like molecules in the retina, retinotectal pathway, and optic tectum of the frog. J. Neurosci. 9: 565-573.

Schuetze, S. M., and L. W. Role (1987) Developmental regulation of nicotinic acetylcholine receptors. Annu. Rev. Neurosci. 10:403-457.

Slot, J. W., and H. J. Geuze (1981) Sizing of protein A-colloidal gold probes for immunoelectron microscopy. J. Cell Biol. 90: 533-536.

Slot, J. W., and H. J. Geuze (1985) A new method of preparing gold probes for multiple-labeling cytochemistry. Eur. J Cell Biol. 38: 8793.

Swanson, L. W., J. Lindstrom, S. Tzartos, L. C. Schmued, D. D. M. O'Leary, and W. M. Cowan (1983) Immunohistochemical localization of monoclonal antibodies to the nicotinic acetylcholine receptor in chick midbrain. Proc. Natl. Acad. Sci. USA 80: 4532-4536.

Swanson, L. W., D. M. Simmons, P. J. Whiting, and I. Lindstrom (1987) Immunohistochemical localization of neuronal nicotinic receptors in the rodent central nervous system. J. Neurosci. 7: 33343342.

Taxi, J. (1976) Morphology of the autonomic nervous system. In Frog Neurobiology, R. Llinás and W. Precht, eds., pp. 93-150, SpringerVerlag, Heidelberg.

Tzartos, S. J., and J. M. Lindstrom (1980) Monoclonal antibodies used to probe acetylcholine receptor structure: Localization of the main immunogenic region and detection of similarities between subunits. Proc. Natl. Acad. Sci. USA 77: 755-759.

Tzartos, S. J., D. E. Rand, B. L. Einarson, and J. M. Lindstrom (198I) Mapping of surface structures of Electrophorus acetylcholine receptor using monoclonal antibodies. J. Biol. Chem. 256: 8635-8645.

Tzartos, S., L. Langeberg, S. Hochschwender, L. W. Swanson, and J. Lindstrom (1986) Characteristics of monoclonal antibodies to denatured Torpedo and to native calf acetylcholine receptors: Species, subunit and region specificity. J. Neuroimmunol. 10: 235-253.

Tzartos, S. J., A. Kokla, S. L. Walgrave, and B. M. Conti-Tronconi (1988) Localization of the main immunogenic region of human muscle acetylcholine to residues $67-76$ of the $\alpha$ subunit. Proc. Natl. Acad. Sci. USA 85: 2899-2903.

Whiting, P. J., and J. M. Lindstrom (1986) Purification and characterization of nicotinic acetylcholine receptor from chick brain. Biochemistry 25: 2082-2093.

Whiting, P., and J. Lindstrom (1987) Purification and characterization of nicotinic acetylcholine receptor from rat brain. Proc. Natl. Acad. Sci. USA 84: 595-599.

Whiting, P. J., R. Liu, B. J. Morley, and J. M. Lindstrom (1987) Structurally different neuronal nicotinic acetylcholine receptor subtypes purified and characterized using monoclonal antibodies. J. Neurosci. $7: 4005-4016$.

Wigston, D. J. (1987) Repeated imaging of neuromuscular junctions in mouse soleus muscles in vivo. Soc. Neurosci. Abstr. 13: 1007.

Wray, B. E., and R. Sealock (1984) Ultrastructural immunocytochcmistry of particulate fractions using polyvinyl chloride microculture wells. J. Histochem. Cytochem. 31: 1117-1120. 